\title{
HOOP TENSILE CHARACTERIZATION OF SiC/SiC CYLINDERS FABRICATED FROM 2D FABRIC
}

\author{
Michael J. Verrilli \\ NASA Glenn Research Center \\ 21000 Brookpark Road \\ Cleveland, Ohio 44135 \\ HeeMann Yun \\ Cleveland State University \\ Cleveland, Ohio
}

\author{
James A. DiCarlo \\ NASA Glenn Research Center \\ 21000 Brookpark Road \\ Cleveland, Ohio 44135
}

Terry R. Barnett

Southern Research Institute

757 Tom Martin Drive

Birmingham, Alabama

\begin{abstract}
Tensile stress-strain properties in the hoop direction were obtained for 100-mm diameter $\mathrm{SiC} / \mathrm{SiC}$ cylinders using ring specimens machined from the cylinder ends. The cylinders were fabricated from $2 \mathrm{D}$ balanced fabric with several material variants, including wall thickness $(6,8$, and 12 plies), SiC fiber type (Sylramic, Sylramic-iBN, Hi-Nicalon, and Hi-Nicalon S), fiber sizing type, and matrix type (full CVI SiC, and partial CVI plus melt-infiltrated SiC-Si). Fiber ply splices existed in the all the hoops. Tensile hoop measurements were made at room temperature and $1200^{\circ} \mathrm{C}$ using hydrostatic ring test facilities. The hoop results are compared with in-plane data measured on flat panels using same material variants, but containing no splices.
\end{abstract}

\section{INTRODUCTION}

Silicon carbide fiber-reinforced silicon carbide $(\mathrm{SiC} / \mathrm{SiC})$ composites are being evaluated for use as a combustor liner material for gas turbine engines [16]. Many CMC combustor designs are fully annular [4-6] and are often structurally analyzed using data generated from specimens machined from flat panels. Typical annular combustor liner operation requires the $\mathrm{SiC} / \mathrm{SiC}$ material to resist thermal gradients that produce tensile and compressive stresses in the circumferential (hoop) direction and bending stresses in the axial direction [7]. However, the structural properties of CMC parts can sometimes be significantly different than those of panels because of changes in fiber architecture required to make shapes and because of difficulties in replicating panel processing conditions [8]. To assess whether property issues could exist even for simple combustor designs, tensile stress-strain curves were measured in the hoop direction for

This report is a preprint of an article submitted to a journal for publication. Because of changes that may be made before formal publication, this preprint is made available with the understanding that it will not be cited or reproduced without the permission of the author. 
$\mathrm{SiC} / \mathrm{SiC}$ cylinders with several material variants, including wall thickness, fiber type, and matrix type. The purpose of this paper is to report the hoop tensile properties of these different $\mathrm{SiC} / \mathrm{SiC}$ materials and to compare these properties to those obtained from flat panels fabricated with the same constituents.

\section{EXPERIMENTAL}

\section{Materials and Specimens}

Eight $250-\mathrm{mm}$ long $\mathrm{SiC} / \mathrm{SiC}$ cylinders were fabricated from 2D-balanced 5-harness satin [0/90] fabric by GE Power Systems Composites. Material variations of the 100 -mm diameter cylinders included wall thickness $(6,8$, and 12 plies), SiC fiber type (Sylramic, Sylramic-iBN, Hi-Nicalon, and Hi-Nicalon type S), fiber sizing type (1 and 2), and matrix type (full CVI SiC, and partial CVI plus melt-infiltrated (MI) SiC-Si). Use of sizing 2 in Sylramic-reinforced MI SiC composites results in improved high temperature panel properties when compared to the same composite fabricated with sizing 1 [8]. All cylinders had a volume fraction of $35+/-3 \%$ of $\mathrm{BN}$-coated fibers, which were aligned along the axial and hoop [0/90] directions. One butt splice running along the axial direction was used to join each fabric ply around the cylinder circumference. For example, an eight ply cylinder had eight ply splices $45^{\circ}$ apart. To minimize structural interactions, splices in adjacent plies were separated by $120^{\circ}$ in the circumferential direction. Table I lists key constituents for each cylinder.

A ring specimen of $10.1 \mathrm{~mm}$ in height was machined from each end of each cylinder. One specimen from each cylinder was tested at room temperature and one specimen from seven of the eight cylinder types was tested at $1200^{\circ} \mathrm{C}$.

Table I - SiC/SiC material constituents for cylinders tested.

\begin{tabular}{clcccc}
\hline ID & Fiber Type & Fiber v/o & EPI $^{*}$ & Plies $^{* *}$ & Matrix Type \\
\hline 021 & Hi-Nicalon & 33.8 & 17 & $\mathbf{8}$ & (CVI + MI) SiC-Si \\
003 & Hi-Nicalon type S & 33.4 & 18 & $\mathbf{8}$ & (CVI + MI) SiC-Si \\
005 & Sylramic with sizing 1 & 38 & 20 & $\mathbf{8}$ & (CVI + MI) SiC-Si \\
007 & Sylramic with sizing 2 & 38 & 20 & $\mathbf{8}$ & (CVI + MI) SiC-Si \\
013 & Sylramic-iBN & 35.6 & 20 & 6 & (CVI + MI) SiC-Si \\
015 & Sylramic-iBN & 37.2 & 20 & 12 & (CVI + MI) SiC-Si \\
009 & Sylramic with sizing 2 & 38 & 20 & $\mathbf{8}$ & (full CVI) SiC \\
017 & Sylramic-iBN & 32.8 & 20 & $\mathbf{8}$ & (full CVI) SiC \\
*PI $=$ tow ends per inch & $* *$ wall thickness $\sim 0.25$ mm per ply
\end{tabular}

\section{Test Procedures}

Hoop tensile properties were obtained using hydrostatic ring test facilities [7]. The ambient temperature facility applies pressure to the inner diameter of the rings using hydraulic oil in a rubber bladder. The rubber bladder mates to the inner diameter of the ring specimens, causing expansion of the specimens. A pressure transducer measures the hydraulic oil pressure applied to the rings via the bladder. The tensile hoop stress $(\sigma)$ can be calculated using mechanics of 
materials relationships for thin walled pressure vessels: $\sigma=p r / t$, where $p=$ internal pressure, $r=$ inner radius of the ring, and $t=$ wall thickness. A string was wrapped around the outside of the hoops and attached to two LVDTs in order to measure outer-diameter circumferential strain with applied pressure. Two strain gages, applied $180^{\circ}$ apart on the outside of the rings, were also used to measure strain.

A similar procedure was used to obtain hoop tensile properties at $1200^{\circ} \mathrm{C}$. The elevated temperature facility includes 18 cooled wedges that mate with the inner diameter of the hoop specimens. Hydraulic pressure is applied through a rubber bladder, which mates with the inner diameter of the wedges. The cooled wedge configuration is required to maintain the bladder near room temperature while heating the specimens to elevated temperatures using a resistively heated furnace. Strain was measured using LVDTs in a similar fashion as used for room temperature testing. Stress was calculated at $1200^{\circ} \mathrm{C}$ using the same formula used at $25^{\circ} \mathrm{C}(\sigma=\mathrm{pr} / \mathrm{t})$. The applicability of this relationship to calculate stress in the elevated temperature facility was verified at room temperature using an instrumented aluminum calibration ring.

In-plane tensile properties were also obtained using $25-\mathrm{mm}$ gauge length dog-boned specimens from $\mathrm{SiC} / \mathrm{SiC}$ panels manufactured by GE Power Systems Composites with the same constituents and fabric architectures used to make the cylinders, but without the presence of ply splices. The test procedures followed those recommended by ASTM [9].

\section{RESULTS AND DISCUSSION}

Figures $1 \mathrm{a}$ and $1 \mathrm{~b}$ compare the ultimate strength, strain, and modulus for the eight cylinders at room temperature and $1200^{\circ} \mathrm{C}$, respectively. To compare the hoop tensile properties from single specimens of each of the eight different materials, property standard deviations shown in Figure 1 were determined from 24 hoop tensile tests on similar diameter $\mathrm{SiC} / \mathrm{SiC}$ combustor cans fabricated for rig testing [10]. These combustor cans had the same constituents as cylinder 005 (Table I). These tests yielded standard deviations in hoop strength, strain, and modulus of $15.2 \mathrm{MPa}, 0.008 \%$, and $16.3 \mathrm{GPa}$, respectively.

Figure la shows that the room temperature hoop strengths for the eight cylinders were generally similar (about 200-220 MPa). Exceptions existed for the one cylinder with Hi Nicalon type S (003) and the one cylinder with Sylramic fibers in CVI full SiC matrix (009), which had lower strengths. Hoop failure strains generally correlated with the strength values. Exceptions were the cylinder reinforced by the Hi-Nicalon fibers $(021)$, which displayed strains higher than predicted based on elastic behavior, and the cylinder reinforced by Hi-Nicalon $\mathrm{S}$ (003) and cylinder 017 (Sylramic-iBN/CVI SiC matrix), which had lower failure strains.

For the hoop tensile properties obtained at $1200^{\circ} \mathrm{C}$, Figure $1 \mathrm{~b}$ shows that in essentially all cases, ultimate strengths and strains were about $70 \%$ of their room temperature values, and elastic moduli were slightly changed at about 90 - 
$100 \%$ of their room temperature values. An exception was the Sylramic fiber reinforced MI cylinder (007), which retained $50 \%$ of the strength relative to the room temperature panel strength and also had the highest modulus.

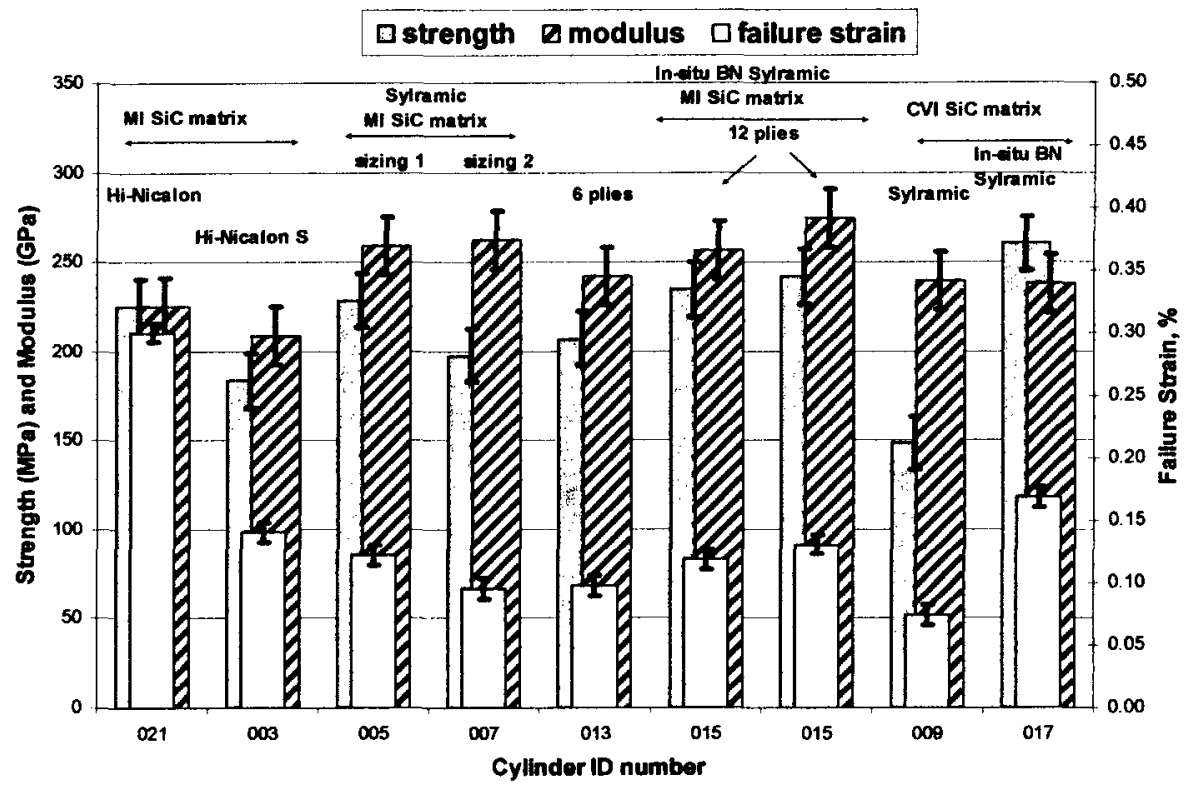

(a)

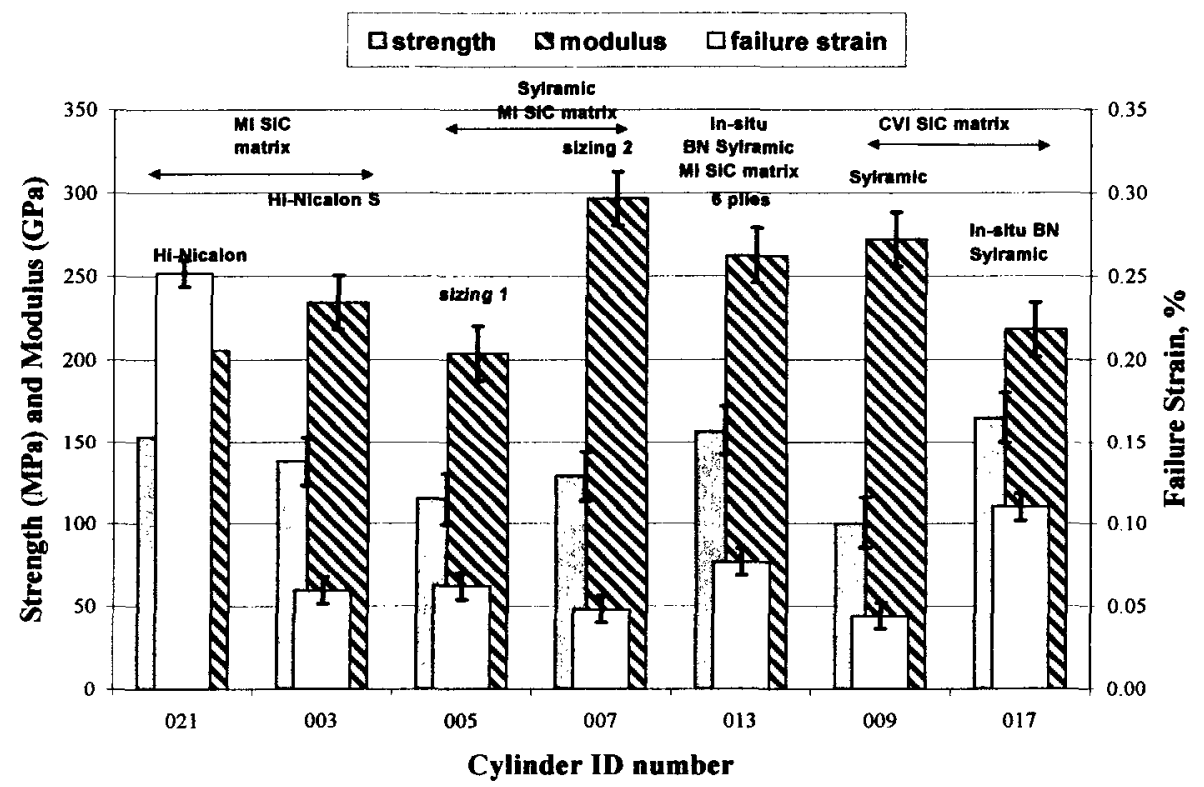

(b)

Figure 1 - Ultimate strength, strain, and modulus for $\mathrm{SiC} / \mathrm{SiC}$ cylinders:

(a) at room temperature; (b) at $1200^{\circ} \mathrm{C}$. 


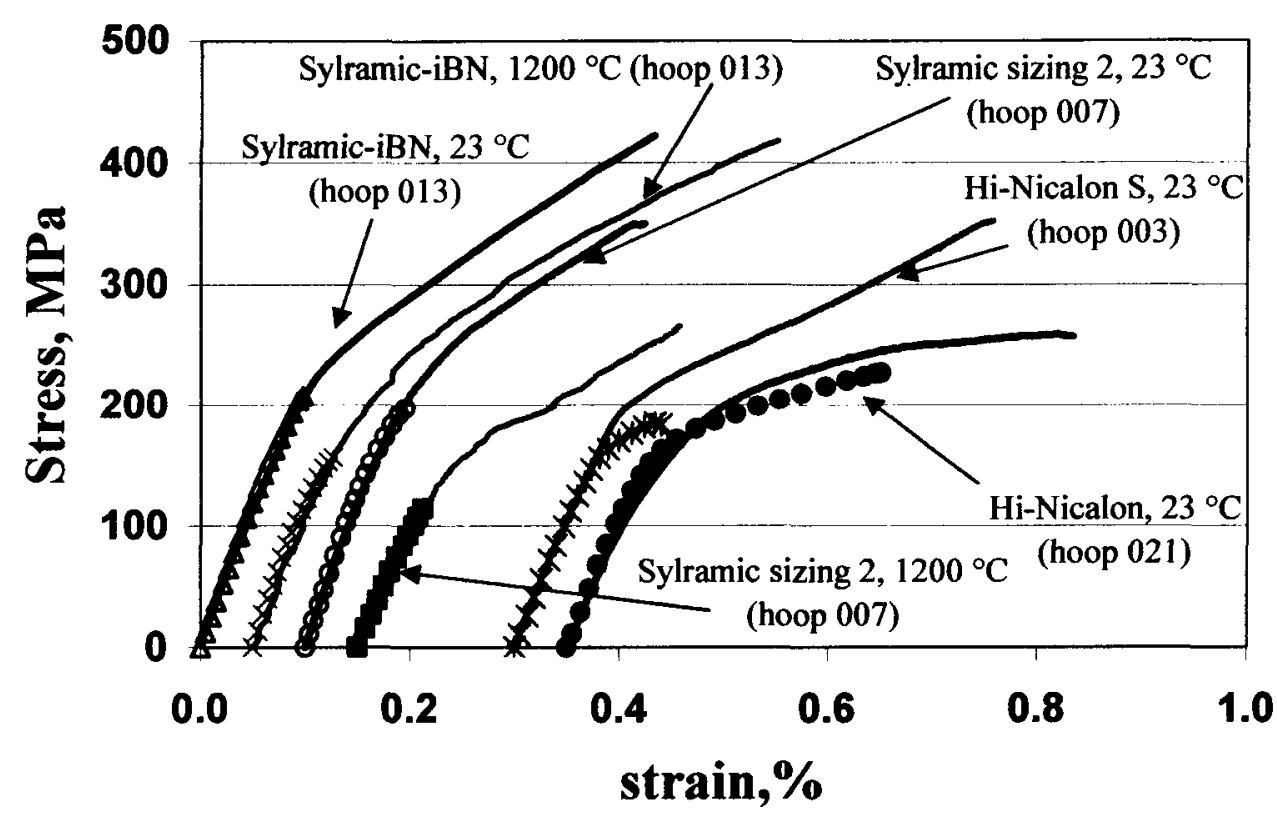

Figure 2 - Room temperature and $1200^{\circ} \mathrm{C}$ stress-strain behavior for $\mathrm{SiC} / \mathrm{SiC}$ rings and panels fabricated using the same constituents. All specimens tested had a CVI + MI matrix. The lines are panel data and the symbols are data for the hoops.

The room temperature and $1200^{\circ} \mathrm{C}$ stress-strain curves for several cylinders are compared to that for panels fabricated from the same constituents in Figure 2. Data for the different materials are offset along the strain axis. Both the hoop and panel specimen have the same initial tensile behavior. At room temperature, the hoops failed at a stress that was about $50 \%$ of the panel strength. The $1200{ }^{\circ} \mathrm{C}$ hoop strength was about $40 \%$ of panel strength. Because of the linear-elastic behavior, cylinder ultimate strain was considerably less then that for panels (about 25 and $17 \%$ of panel failure strain at room temperature and 1200 ${ }^{\circ} \mathrm{C}$, respectively). The exception was the Hi-Nicalon reinforced MI SiC matrix cylinder (021), which had significant non-linear strain response and had almost $90 \%$ of the room temperature panel strength.

From Figure 2, it can be concluded that the hoops had the same modulus and initial stress-strain behavior as standard tensile measurements on flat panel specimens with the same constituents and fiber architectures. The major differences were the reduced ultimate stress and strain values of the hoops, which can be attributed to local fiber architectural differences caused by the presence of butt ply splices in the hoops. Discontinuous fiber cloth and matrix-rich regions exist in the splices. However, ply splices are necessary when 2D fabric is used to make complex composite parts, such as full annular combustor liners.

One simple explanation for the lower ultimate strength and strain for the cylinders is that at each butt splice, the local fiber volume fraction in the hoop or stress direction was reduced to a factor $(\mathrm{N}-1) / \mathrm{N}$ times the global fiber fraction, 
where $\mathrm{N}$ is the number of plies. For 8-ply cylinder having a nominal $35 \mathrm{v} / \mathrm{o}$ of fibers, the local fiber volume fraction at a splice would be about $30 \%$. Ignoring any $\mathrm{K}_{\mathrm{t}}$ effects, one would expect strength should slightly less (based on a rule of mixtures analysis) than the flat panel strength. However, for composites with the same 2D fabric, ring tensile strength is typically 40 to $50 \%$ of panel specimens (see Figure 2). This suggests that local stress concentrations existed around the butt splices. Since the ultimate strains for the hoops were typically above those required for matrix cracking, it would appear that these stress concentrations probably caused local fiber fracture in neighboring plies, with ultimate specimen fracture likely occurring at one of the 8 butt splices around the ring specimens. Recent tensile data generated on iBN-Sylramic MI panel specimens with splices (the same material constituents in hoops 013 and 015) revealed that the presence of a ply splice on the composite surface reduced strength, but ply splices in the interior plies had little effect the tensile behavior [11]. This suggests that the primary location for ring fracture was at the butt splice for the outer cylinder ply. Studies are on-going to establish whether this was indeed the case.

The Hi-Nicalon hoops had high strengths and failure strains two times greater than any of the other hoop materials, both at room temperature and $\mathbf{1 2 0 0}$ ${ }^{\circ} \mathrm{C}$. One possible reason for these good properties may be that the Hi-Nicalon cylinder was the highest quality of all those produced. Microstructural analyses will be conducted and may help characterize the relative quality of all the cylinders. Another potential explanation may be that since Hi-Nicalon MI composites in panel form typically have higher tensile failure strain than iBNSylramic or Sylramic MI composites [12, 13], this trend may exist in the cylinders having the same constituents. It is important to note that $\mathrm{iBN}-\mathrm{Syl}$ (ramic or Sylramic MI composites in panel form have better high temperature strength and durability than Hi-Nicalon MI composites [12].

\section{SUMMARY AND CONCLUSIONS}

The hoop tensile stress-strain properties were measured at room temperature and $1200^{\circ} \mathrm{C}$ for eight $\mathrm{SiC} / \mathrm{SiC}$ cylinders reinforced with $2 \mathrm{D}$ fiber cloth and fabricated from a variety of constituents. For each temperature, ultimate strength, strain, and elastic modulus were generally similar for the cylinders, but strength and strain values were a significantly lower fraction, about 40 to $50 \%$ and about $20 \%$, respectively, of those measured for flat $\mathrm{SiC} / \mathrm{SiC}$ panels fabricated with the same $2 \mathrm{D}$ fabric and constituents. Ultimate strength and strain debits were caused by the presence of butt ply splices, which were needed to join plies along the axial direction of the cylinders. The large amount of knockdown is attributed to reduced fiber content at the butt splices and to further fiber loss during matrix cracking at the splices. 


\section{REFERENCES}

1. Brewer, D., Ojard, G., and Gibler, M., "Ceramic Matrix Composite Combustor Liner Rig Test”, ASME paper TE00CER03-03, May, 2000.

2. Ojard, G., Stephan, R., Naik, R., Gibler, M., Cairo, R., Linsey, G., Hornick, J., and Brewer, D., "NASA Rich Burn Quick Quench Lean Burn Sector Rig $\mathrm{SiC} / \mathrm{SiC}$ CMC Testing", in proceedings of $24^{\text {th }}$ Annual Conference on Composites, Materials, and Structures, Cocoa Beach, FL., Jan., 2000.

3. Corman, G., Dean, A., et. al, "Rig and Gas Turbine Testing of MI-CMC Combustor and Shroud Components", ASME paper 2001-GT-0593, 2001.

4. Shi, J.,"Design, Analysis, Fabrication and Testing of a CMC Combustion Can", ASME paper 2000-GT-71, 2000.

5. Miriyala, N., Kimmel, J., Price, J., More, K., Tortorelli, P., Eaton, H., Linsey, G., and Sun, E., "The Evaluation of CFCC Liners after Field Testing in a Gas Turbine - III", ASME paper GT-2002-30585, 2002.

6. Igashira, K.-I., Matsubara, G., Matsuda, Y., and Imamura, A., "Development of the Advanced Combustor Liner Composed of CMC/GMC Hybrid Composite Material", ASME paper 2001-GT-0511.

7. Barnett, T. R., Ojard, G. C., and Cairo, R. R., "Relationships of Test Methods and Standards Development to Emerging Retrofit CFCC Markets", in ASTM STP 1392, M. G. Jenkins, E. Lara-Curzio, and S. T. Gonczy, Eds., American Society for Testing and Materials, West Conshohoken, PA, 2000.

8. DiCarlo, J.A., and Yun, H.M., NASA Glenn Research Center, unpublished research.

9. ASTM Standard C 1359-96, "Standard Test Method for Monotonic Tensile Strength Testing of Continuous Fiber-Reinforced Advanced Ceramics with Solid Rectangular Cross-Section Specimens at Elevated Temperatures", Annual Book of ASTM Standards, vol. 15.01, 2000.

10. Verrilli, M. J., Martin, L. C., and Brewer, D. N., "RQL Sector Rig Testing of SiC/SiC Combustor Liners", NASA TM 2002-211509, April 2002.

11. Calomino, A. and Verrilli, M. J., "Mechanical Performance Improvements of an In-situ Boron Nitride-coated $\mathrm{MI} \mathrm{SiC/SiC} \mathrm{Composite",} \mathrm{in} \mathrm{the} \mathrm{proceedings}$ of the $26^{\text {th }}$ Annual Conference on Composites, Materials, and Structures, held in Cocoa Beach, FL, Jan. 28-31, 2002.

12. Yun, H.M., DiCarlo, J.A., and Bhatt, R.T., "Structural Advantages of the Sylramic-iBN SiC Fiber for SiC/SiC Components", these proceedings, 2003.

13. H.M. Yun and J.A. DiCarlo, "Effects of 2-D Fabric Geometry on the Tensile Strength of Stoichiometric SiC Fiber-Reinforced Composites", in High Temperature Ceramic Matrix Composites, W. Krenkel, R. Naslain, and H. Schneider, Eds, Wiley-VCH, Weinheim, Germany, 2001, pp. 99-105. 